\title{
Areas designated for afforestation and areas excluded from afforestation - selected aspects related to the protection of the landscape in view of Poland experience
}

\author{
Barbara Żarska, Beata Fornal-Pieniak, Ewa Zaraś-Januszkiewicz \\ Warsaw University of Life Sciences, Faculty of Horticulture, Biotechnology and Landscape Architecture, \\ Department of Environmental Protection, \\ St. Nowoursynowska 166, 02-787 Warsaw, Poland, \\ e-mail: barbara_zarska@sggw.pl
}

\begin{abstract}
In connection with the implementation of the National Programme for Forest Cover Growth in Poland, environmental preconditions, national, EU and international legal requirements as well as necessity of the implementation of green economy in the framework of adaptation to climate change and regarding implementation of sustainable development, increase of total forest cover is very beneficial. However, decisions on afforestation should be thought out. The aim was to draw attention to the more important arguments and principles, supported by scientific and practical facts, in which cases: afforestation is much needed, afforestation is forbidden/not indicated and which terrains should be excluded from deforestation. In particular the aspects related to protection of the landscape have been highlighted. The landscape is understood as a synthesis of the natural, cultural and visual environment. Due to the fact that the first two groups of arguments and principles are generally well known, more focused on the areas and cases where afforestation is not allowed or not advisable. Sites should be excluded from afforestation in particular as a result of circumstances such as: 1) the necessity of coexistence, next to forests, other valuable elements of landscape ecological structure, including water and semi-natural ecosystems (e.g. in Nature 2000 areas), 2) occurrence of valuable terrestrial non-forest ecosystems, 3) protection of proper exposure of landscape dominants (cultural, natural or mixed), creation of exposure of valuable views, panoramas, creating view axes, 4) valuable forms of terrain relief and, in case where are landscape dominants, as well terrains around them. The set of rules where afforestation and exclusion from afforestation is needed, has been presented being, at the same time, the set of indications for shaping the environment, the landscape and the land-use planning in terms of the formation of the spatial structure of forest areas in Poland.
\end{abstract}

Key words: afforestations, attractiveness of landscape, deforestations, forests, landscape protection.

\section{Introduction}

Due to the need to implement and realize the national programme for the increase of forest cover in Poland to $33 \%$ to 2050 (National Programme for Forest Cover Growth, www.lasy.gov.pl, 2014), environmental needs (sustainable development, ecological balance, water balance, nature protection) as well as national, European Union and international legal requirements (COM/2011/0244, COM/2013/0249, BD Convention, Bern Convention, projected convention on forests' protection and sustainable use and others), the increase of forest share in total area is very beneficial. It correlates well with climate change and mitigation of climate change negative results, among others transition to green economy (EEA 2010; Towards Green Economy 2011), according to the EU Strategy on Adaptation to Climate Change (COM/2013/216 final). However, decisions on afforestations should be reasonable.

The aim was to indicate more important arguments and rules of landscape planning, obtained on the base of scientific research results and practical experiences in Poland area, in which cases: 1) the afforestation of the area is 
needed, 2) the afforestation is forbidden or not preferred and 3) terrains should be excluded from deforestation. The aspects relating from protection of natural and aesthetic values of landscape have been specially highlighted. Partly specific experiences in Poland area can contribute the state of knowledge in this range.

\section{Methods}

It is based on the synthesis from long-term scientific research and practical experience of Authors in consulting protective actions and changes of land use (ex. membership in the Regional Council for Conservation of Nature and other bodies on spatial management and landscape planning) as well solving problems in terms of searching for balance between development and environmental protection and landscape quality. It is also based on the review of scientific literature concerning case studies and experience mainly in the geographic zone of Poland.

\section{Results of source material analysis}

\subsection{Where is the afforestation needed?}

Arguments for afforestation and benefits from forests have been commonly known so are not broadly commented in this paper: only few special aspects are raised. Environmental preconditions for afforestations are very wide and derive from natural characteristic of the bioregions in which Poland is localized: forests are the most perfect type of terrestrial ecosystems in these geographic zones. Achievement of ecological balance in regions, required by legal acts (Ustawa Prawo ochrony środowiska 2001), is not possible without greater share of forest cover in total area. Forest share has a direct connection with environment state quality. Districts with high forest cover usually need lower financial measures for environment protection (no need to restore firmly transformed environment) than areas of low afforestation (Żarska 2006; Ochrona środowiska 2014). Forests are one of main elements of landscape ecological structure - important building elements of systems of natural areas at national, regional and local level of landscape planning (Żarska 2006; Żarska et al. 2014). Despite the fact that forestry management has been conducted in the most of woodland areas, forests are the place of occurrence of natural species of flora and fauna and biocoenosis of natural character. The set of crucial principles in which cases the afforestation is needed can be formulated as below.

Principle 1: protect existing woodlands and afforest terrains to gain greater ecological benefit in relatively shorter time.
In realization of programme of forest cover growth it is advisable to be guided by the principle 'greater ecological benefit in a shorter time' (Cieślak 1996; Żarska 2006), because of intensive process of wild species extinction. It means that if there is the choice let first afforest terrains where the introducing of forest use gives greater natural benefits in a relatively short period, for example afforestations causing: enlargement of existing forest complexes (natural refuges), improvement of continuity of ecological corridors and building of buffer zones around vulnerable natural areas. If the distance between two main natural refuges is very big, there is a need do shape by-way natural refuges along the ecological corridor connecting them (to make migration more efficient). Effective protection and long-term survival of forest species being ecological specialists (co-called species of forest interior) is possible only in big-sized forest complexes which are well ecologically connected with other natural refuges (Lovejoy \& Oren 1981; Cieślak 1996; Żarska 1996; Żarska 2006; FornalPieniak \& Olik 2013; Fornal-Pieniak et al. 2014; Żarska et al. 2014). The minimum critical size of natural refuge should be measured by territorial and life needs of large predators. For this reason, even the largest protected areas in Poland are too small for assuring good living conditions for enough-numerous populations of wild species of big predators, so ecological corridors should be shaped.

Principle 2: afforest to create big-sized forest complexes.

One big-sized forest complex has on average more woody species than a few small forest complexes of total area equal to the surface of this large forest (on the similar habitat) (Dzwonko \& Loster 1989). So the aim of landscape shaping should be to create big-sized woodlands by afforestations.

Principle 3: afforest to create buffer forest zones around surface waters and wetlands.

The next important course in afforestations is to create protecting buffer zones in surroundings of surface waters and wetlands as well as in watershed and water spring areas (Żelazo 1996; Jermaczek ed. 2008; Żarska 2011; Żarska et al. 2014). Formation of protecting buffer zones around valuable and vulnerable natural areas means not only setting up of legal protection, but projecting and introducing friendly land use in neighbourhood is needed in every case. For example such land use as orchards localized next to forests, wetlands or waters are very inadvisable. Arable lands next to forests are better than intensive building area as well as single family building in the vicinity is much friendly to forests than intensive development.

Principle 4: consciously use forests (and afforestations) for creation of spatial composition of high visual values in the landscape.

Forests have a great importance in creation of high visual values of landscape. This function of woodlands has 
been often underestimated or forgotten. Woods in the landscape usually influence the improvement of spatial composition and order. Forests play an important role in the landscape structure particularly in following manner (Źarska 2000; Żarska et al. 2014): 1) distinguish landscape interiors (forests are usually walls of landscape interiors), 2) play a role of landscape dominants or subdominants (forests are magnificent and strong elements of spatial compositions), 3 ) are a perfect background for exposition of valuable cultural dominants or dominants of inanimate nature, 4) help to hide dissonance elements in the landscape. The rule of harmony of natural landscapes has been formulated (Żarska 2011). It is that these landscapes have an inborn feature of harmony. Forests are natural type of plant formation so occurring in the landscape increase the extent of harmony of spatial composition. The visual meaning of forests is very spectacular as well as their natural function and economic importance.

Principle 5: maintain and protect forests of natural character (reminding climax vegetation) and afforest around them to create buffer zones and bigger forest interiors.

It is important not to disturb forest phytocoenoses, particularly these similar to the natural. Such forest ecosystems are quite resistant to anthropopressure including penetration of alien species (Kornaś \& Medwecka-Kornaś 1967, 1968; Żarska 1994, 2006). Disturbance of these woodlands by cuttings (clearings), crossing with roads and introducing of buildings into forest interiors causes decrease of their resistance to anthropopressure.

Principle 6: harmonisation between programmes of afforestation and plans of introducing woodlots and shelterbelts in arable lands and other vulnerable terrains is needed.

Plantings support well forests in their ecological and protective functions. In some areas there is no possibility to introduce a lot of afforestations, for example in terrains which are very suitable for agriculture, so woodlots are a good way to achieve greater ecological benefits.

\subsection{Where is the afforestation forbidden or not preferred?}

Increase of forest share in total area is generally very beneficial as regards environmental conditions of Poland and the Central Europe. Although there are some cases and situations where afforestations should be forbidden or not preferred. Some important basic principles can be formulated as regards these aspects.

Principle 1: maintain or protect areas consist of few types of natural and semi-natural ecosystems (do not afforest everywhere).

This is one of these special cases where introducing of woods may be at least not indicated. It usually follows from requirements of nature conservation as well as economic needs (Jermaczek ed. 2008; Pullin 2004; Żarska 2006). Native species of animals (including protected species and species important for European Community) often need a few types of habitats (natural and semi-natural usually) to live, for example they require big-sized forest complexes, water environment and meadows (for example black stork). It is also important for high biological diversity, balance between nature protection and management and aesthetic values of landscape.

Principle 2: do not afforest valuable non-forest terrestrial ecosystems. Important non-forest ecosystems should be taken carefully into account, among others xerothermic grasslands, to avoid afforestation. The recognition and diagnosis of unique non-forest ecosystems are needed very much before or in correlation with the program of afforestation in the administered area.

Principle 3: do not afforest unique, valuable or magnificent forms of terrain relief and their surroundings. Afforestation of such elements hides them or even destroys and makes their scientific values difficult to use and see as well as it causes the loss of landscape quality (Photo 1). These valuable forms of relief should be left as uncovered and exposed in the landscape and, if needed, managed as meadows.

Principle 4: do not afforest in the vicinity of valuable landscape dominants - in areas of exposition zones, as well as in areas of scenic axes (Photo 2 and 3). Protection of visual environment is very important because it is a public good having a great meaning for perception comfort, aesthetic quality and tourist attractiveness of landscape. Forests generally help to keep and shape perfect landscape composition of high aesthetic features, however on condition not to cover or hide valuable elements and views.

Principle 5: avoid direct spatial contact between such forms of spatial management like orchards and forests. Orchards are usually great threats for species of wild flora and fauna because of intensive application of crop protection chemicals. So orchards should be separated from forests, wetlands and waters by arable lands (Żarska 2006; Żarska et al. 2014). Orchards of 'ecological' production are less dangerous for environment and old traditional orchards are not harmful.

\subsection{Terrains excluded from deforestation}

Situations, in which deforestation is forbidden or not indicated, should be listed separately because of its importance and specificity. Some main principles can be formulated for this reason as well.

Principle 1: do not remove forests in areas of natural refuges and ecological corridors. Fragmented forests worse resist threats, loose their biotop interiors and ecological 


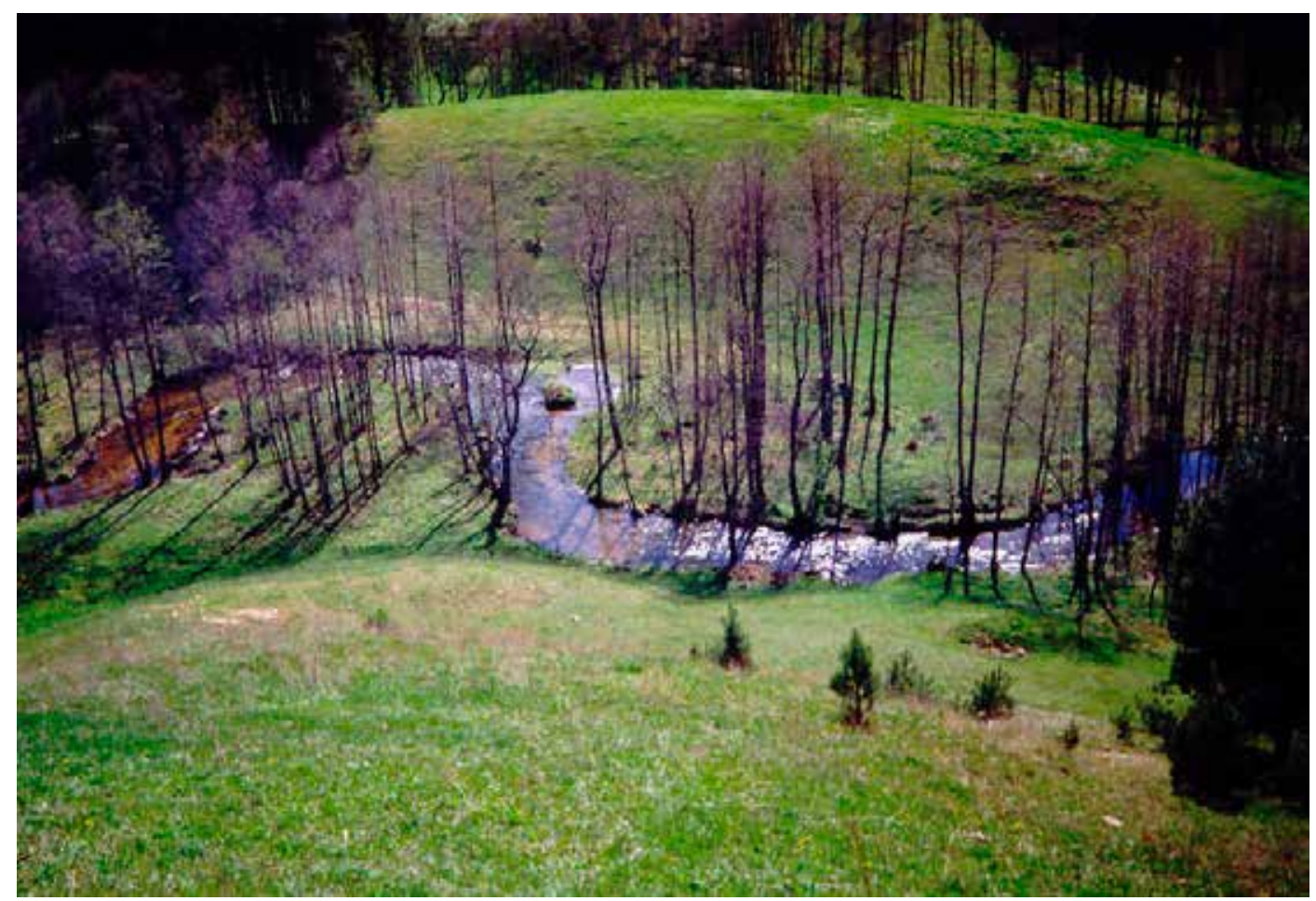

PHOTO 1. Unique and magnificent forms of terrain relief should be excluded from afforestation. Turtul esker - object on the list of the world geosites. Suwalski Landscape Park, north-eastern Poland



PHOTO 2. Deforestation made for landscape opening to enable view at Bobolice medieval castle. The proper decision should be made much earlier: not to afforest this fragment of the terrain. Eagles' Nests Landscape Park, south-central Poland 


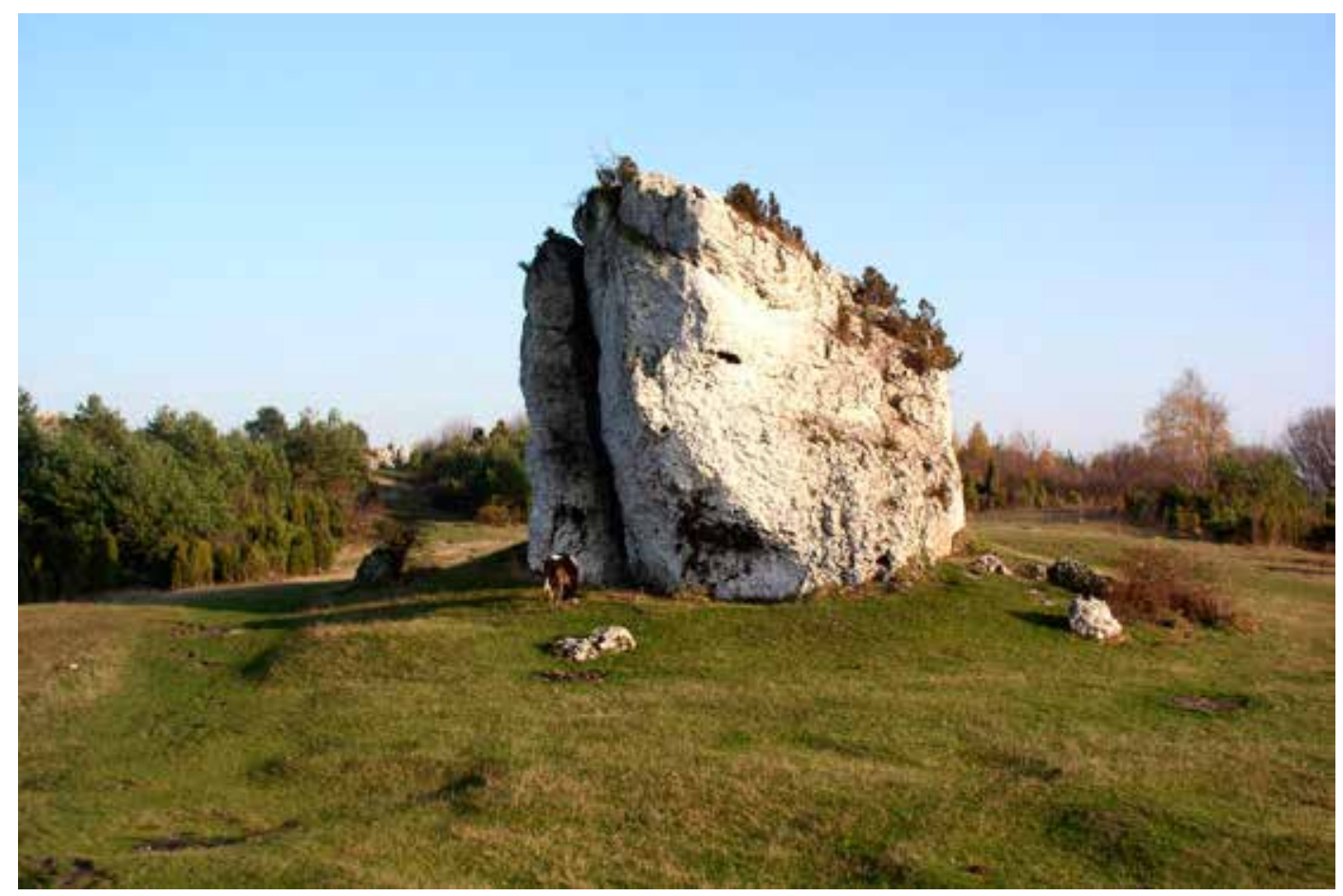

PHOTO 3. Areas of exposition of landscape dominants, scenic views and visual axes should be excluded from afforestation. The picturesque rock as the landscape dominant on the tourist trail. Eagles' Nests Landscape Park, south-central Poland

balance as well make troubles for wild animal migration. The role 'do not disturb what is valuable' should be upheld.

Principle 2: do not deforest on steep and semi-steep slopes (protection against erosion - endangerments of landslides, solifluction, downcreeping and mudflows). It is crucial especially in mountains and hills areas as well in steep and sloping banks of lakes and other surface waters.

Principle 3: do not remove forests in areas closed to surface waters, in wetlands and headwaters terrains. These woods are protective belts of vegetation against surface pollutants and helping to gain better water balance and water quality.

Principle 4: do not deforest in areas of dunes (seaside and inland dunes). These areas are very vulnerable and exposed to slope and wind erosion.

Principle 5: do not deforest in loess areas - in zones of loess gorges, gorge foreheads and edges. Loess terrains have special character of landscape: plateau is used as arable lands (great fertility) and gorges are managed as forests, together making unique scenic and functional type of space and landscape. These principles should be carefully taken into account by administrative and local authorities and economic entities in management and decision process.

\section{Conclusions}

The following conclusions can be drawn from the above findings:

1. Increase of forest cover is generally needed and very beneficial in geographic zones where forests are the type of climax vegetation - regarding ecological, economic and social functions, including protection of natural habitats and species of wild flora and fauna.

2. Although forests are generally very desirable, necessary and beneficial in the landscape, there are same important cases/situations in which afforestation is forbidden or at least not indicated as well deforestation is not allowed. All these aspects, associated with rational land use, nature conservation and protection of visual values, should be carefully taken into account in management of areas.

\section{References}

Cieślak M., 1996, Zagrożenia i kierunki ochrony różnorodności biologicznej rozdrobnionych kompleksów leśnych [Risks and guidelines in the biodiversity conservation of fragmented forests], Wyd. Instytutu Ochrony Środowiska, Warszawa. 
COM/2011/0244 (final report), 2011, Communication from the Commission to the European Parliament, the Council, the European Economic and Social Committee and the Committee of Regions: Our life insurance, our natural capital: an EU biodiversity strategy to 2020, http://eur-lex.europa.eu [Accessed: 10.10.2014].

COM/2013/216, 2013, Communication from the Commission to the European Parliament, the Council, the European Economic and Social Committee and the Committee of the Regions: An EU Strategy on adaptation to climate change, http://europa.eu/news/environment [Accessed: 12.12.2014].

COM/2013/0249, 2013, Communication from the Commission to the European Parliament, the Council, the European Economic and Social Committee and the Committee of Regions: Green Infrastructure (GI) - Enhancing Europe's National Capital, 06.05.2013, http:// eur-lex.europa.eu [Accessed: 16.09.2014].

Dzwonko Z. \& Loster S., 1989, Distribution of vascular plant species in small woodlands on the Western Carpathian foothills, Oikos 56: 77-86.

EEA, 2010, Środowisko Europy 2010 - stan i prognozy. Synteza. Europejska Agencja Ochrony Środowiska [The European Environment 2010 - state and outlook. Synthesis. European Environment Agency], Kopenhaga, http://www.eea.europa.eu [Accessed: 14.05.2014].

Fornal-Pieniak B. \& Olik M., 2013, Diversity of flora in undergrowth of afforestations, rural plantings and oak-hornbeam forests, Folia Forestalia Polonica, ser. A, 55(3): 132-136.

Fornal-Pieniak B., Olik M., Zaraś-Januszkiewicz E. \& Żarska B., 2014, Diversity of ancient species in urban forests, Folia Forestalia Polonica, ser. A, 56(2): 116-117.

Jermaczek A. (ed.), 2008, Zalesiać czy nie zalesiać? [Should we afforest or should we not?], Wyd. Klubu Przyrodników, Świebodzin.

Kornaś J. \& Medwecka-Kornaś A., 1967, The status of introduced plants in the natural vegetation of Poland, Proceedings and Papers of the IUCN $10^{\text {th }}$ Technical Meeting, IUCN Publ. New Ser., Morges: 9.

Kornaś J. \& Medwecka-Kornaś A., 1968, Występowanie gatunków zawleczonych w naturalnych i półnaturalnych zespołach roślinnych w Polsce [The occurrence of introduced plants in natural andsemi-natural plant communities in Poland], Materiały Zakładu Fitosocjologii Stosowanej Uniwersytetu Warszawskiego 25: 55-63.
Ochrona środowiska, 2014, Główny Urząd Statystyczny [Envirinmental Protection, Major Statistical Office], Warszawa.

Lovejoy T.E. \& Oren D.C., 1981, The Minimum Critical Size of Ecosystems, [in:] R.L. Burgess, D.M. Sharpe (eds) Forest Islands Dynamic in Man-Dominated Landscapes, Ecological Studies Vol. 41: 7-12, Springer-Verlag, New York.

Pullin A.S., 2005, Biologiczne podstawy ochrony przyrody [Conservation Biology], Wydawnictwo Naukowe PWN, Warszawa.

National Programme for Forest Cover Growth, 2014, Ministry of Environment in Poland, www.lasy.gov.pl [Accessed: 13.12.2014].

Towards Green Economy, 2011, Pathways to Sustainable Development and Poverty Eradication. Green Economy Report, UNEP, www.unep.org/greeneconomy [Accessed: 13.09.2014].

Ustawa z dnia 27 kwietnia 2001 roku Prawo ochrony środowiska [Polish Act of Law of 27.04.2001 on Environmental Protection ], consolidated act: the Journal of Laws No 25/2008.150 with amendments, www.isap. sejm.gov.pl [Accessed: 12.08.2015].

Żarska B., 1994, Wpływy ekotonowe w roślinności strefy brzegowej lasów a kształtowanie zalesień [Ecotone effects in vegetation of marginal zones of forests and forest area planning], Ochr. Środ. i Zasob. Nat. 8: 13-25.

Żarska B., 1996, Znaczenie wielkości powierzchni kompleksu leśnego dla skuteczności ochrony leśnych zasobów genetycznych roślin [The importance of forest complex area size for protection of genetic resources of woods], Ochr. Środ. i Zasob. Nat. 9: 93-103.

Żarska B., 2000, Aestethic and landscape values of forests, Ann. Warsaw Agricult. Univ. SGGW, Horticult. Landsc. Architect. 21: 159-169.

Żarska B., 2006, Modele ekologiczno-przestrzenne i zasady kształtowania krajobrazu gmin wiejskich [Ecological and spatial models and principles of landscape planning in rural communes], Wyd. SGGW, Warszawa.

Żarska B., 2011, Ochrona krajobrazu [Landscape protection], Wyd. SGGW, Warszawa.

Żarska B., Fornal-Pieniak B., Zaraś-Januszkiewicz E., 2014, Landscape protection and planning: Selected issues, WULS Press, Warsaw.

Żelazo J., 1996, Uwagi o potrzebie i skuteczności pasów brzegowych, Gospodarka Wodna 3(56): 86-91. 